\title{
Effects of regular green tea intake on body fat and arterial stiffness in young adults: A randomized intervention study
}

\author{
Sanami Kobayashi ${ }^{1}$, Chika Nanayama ${ }^{2}$, Noriko Ogawa ${ }^{2}$, Naoyuki Matsumoto ${ }^{3}$ and Masato Nishiwaki ${ }^{1 *}$ \\ ${ }^{1}$ 大阪工業大学工学部， ₹535-8585 大阪府大阪市旭区大宮5-16-1 (Faculty of Engineering, Osaka Institute of Technology, \\ 5-16-1 Omiya, Asahi-ku, Osaka 535-8585, Japan) \\ 2 大阪工業大学大学院化学・環境・生命工学専攻， †535-8585 大阪府大阪市旭区大宮5-16-1 (Graduate Course in Applied \\ Chemistry, Environmental and Biomedical Engineering, Osaka Institute of Technology, 5-16-1 Omiya, Asahi-ku, Osaka \\ 535-8585, Japan) \\ 3熊本県立大学環境共生学部， T862-8502 熊本県熊本市東区月出3-1-100 (Faculty of Environmental Symbiotic Sciences, \\ Prefectural University of Kumamoto, 3-1-100 Tsukide, Higashi-ku, Kumamoto 862-8502, Japan)
}

Received: December 12, 2019 / Accepted: March 9, 2020

\begin{abstract}
Green tea catechins are well known to be one of polyphenols, and its regular ingestion induces body fat reduction in obese individuals. Cocoa polyphenols of high-cocoa chocolate can also improve arterial stiffness. However, it is unclear whether green tea catechins improve body fat and arterial stiffness even in healthy young adults. Therefore, this study aimed to examine the effects of regular green tea intake on body fat and arterial stiffness in young adults. This randomized, controlled, parallel-group intervention study included 53 Japanese college students (mean age, $21.1 \pm 0.1$; men, $n=40$; women, $n=13$ ). They were randomly divided into three groups: control group $(n=14)$, intervention I group $(n=19)$, and intervention II group ( $=20)$. The participants ingested $500 \mathrm{ml} /$ day of commercially available natural water $(0 \mathrm{mg}$ of catechin/day) or green tea (intervention I group, $200 \mathrm{mg}$ of catechin/day; intervention II group, $400 \mathrm{mg}$ of catechin/day) for 4 weeks. After 4 weeks of intervention period, no significant changes in body weight, body mass index, pulse wave velocity, and cardio-ankle vascular index were observed in all groups. However, body fat and carbon dioxide output significantly reduced only in the intervention II group. With the level of catechin concentrations increasing, significant decreasing trends were found in body fat changes and respiratory exchange ratio changes. Therefore, these findings suggest that four weeks of regular green tea intake would reduce body fat, but not arterial stiffness, in young adults.
\end{abstract}

Jpn J Phys Fitness Sports Med, 69(3): 249-259 (2020)

Keywords : body composition, catechin, clinical trial, flavonoid, polyphenols

\begin{abstract}
緒言
ぶどうやブルーベリーなどの果物, 赤ワイン, チョコ レートには, ポリフェノールが豊富に含まれており ${ }^{1-3)}$, 近年, ポリフェノールを含む食品の摂取効果が注目され ている ${ }^{4,5)}$. ポリフェノールは, ベンゼン環に複数の水酸 基が結合した化合物の総称であり，天然物としてはこれ までに8000を超える種類の化合物が同定されている4 ${ }^{4}$. ポリフェノールは, ジフェニルプロパン構造をもつフラ
\end{abstract}

*Correspondence: masato.nishiwaki@oit.ac.jp
ボノイド類や単純フェノール類，または加水分解型（ピ ロガール型) タンニン類, 縮合型（カテコール系）タン ニン類に分類される ${ }^{4)}$. これらのポリフェノールには, 特定保健用食品や機能性食品として認可されている食品 に含まれている成分も多く，摂取することで肥満や心血 管疾患予防などの一定の健康効果が期待できるものもあ る ${ }^{4,5)}$. しかし, 食事やサプリメントとしてポリフェノー ルを摂取した場合, 体内で代謝され化学構造が大きく変 化することで，その機能性がほとんど失われてしまう成 分もある ${ }^{4,5)}$. したがって, 一口にポリフェノールと言っ ても多種多様であり, ヒトを対象とした介入研究によっ 
て, 個々のポリフェノールの摂取効果を詳細に検証する ことが重要である。

ポリフェノールの食品機能性で特に注目されているも のの 1 つに緑茶カテキンがある ${ }^{4,5)}$. 緑茶カテキンは, フ ラボノイド類のフラバノール (カテキン) 類に分類され, 緑茶中には, エピガロカテキンガレート, エピガロカテ キン, エピカテキンガレード，エピカテキンなどのポリ フェノールが主に含まれている ${ }^{6)}$. 先行研究では, マウ スに茶カテキンを含む餙を摂取させると, 脂質利用が促 進することが報告されている ${ }^{6)}$. また，肥満者に対し， 12 週間, カテキン類が豊富に含まれる飲料を摂取させ ると体脂肪が低下することも報告されている ${ }^{7-10)}$ 。この ように, 肥満者を対象とした場合, 継続的な緑茶カテキ ンの摂取で体脂肪の低下が期待できることが知られてい る. しかし, 先行研究で報告されている緑茶カテキン摂 取の介入研究は, 主に初期值が高く, 効果が生じやす いと考えられる中年の肥満者を対象に行われてきた ${ }^{7-9)}$. 仮に, 緑茶カテキンに強力な脂質代謝促進作用や体脂肪 低減効果があるとすれば, 初期值が低い若年の標準体型 者を対象とした場合にも一定の摂取効果が確認されると 考えられるが，若年標準体形者に対する作用については 明らかでなく，検討の余地がある。

一方, 動脈スティフネスは, 動脈壁の硬化度を示す指 標であり, Pulse Wave Velocity (PWV) やCardio-Ankle Vascular Index (CAVI) で評価される ${ }^{11,12)}$. PWVや CAVIは, 加齢に伴い増大し ${ }^{13,14)}$ ，動脈スティフネスの 増大は, 心血管疾患の発症や死亡と強く関連することが 知られている ${ }^{15,16)}$. Nishiwaki et al.は, カカオポリフェ ノールを豊富に含む高カカオチョコレートを 4 週間継続 的に摂取させると, 若年者でさえも PWVやCAVIで評 価した動脈スティフネスが有意に低下することを報告し ている ${ }^{17)}$.このカカオポリフェノールの代表的な主成分 の 1 つにエピカテキンがあり ${ }^{18,19)}$, 緑茶にも共通して含 まれている成分である ${ }^{4)}$ ，さらに，緑茶カテキンの5060\%を占めるエピガロカテキンガレートも, エピカテキ ンと同じポリフェノールのフラボノイド類のフラバノー 儿類に分類される ${ }^{4)}$. これは, カカオポリフェノールと 茶カテキンには, 化合物の基礎骨格を構成する化学構造 が類似するポリフェノールが多数含まれていることを示 している。したがって, 継続的な緑茶カテキンの摂取は, 高カカオチョコレートの場合と同様に ${ }^{17)}$, 動脈スティフ ネスを低下させる可能性があると考えられる。しかし， これまで緑茶摂取量と動脈スティフネスの横断的な関連 が検討されているものの ${ }^{20)}$, 継続的な緑茶摂取が動脈入 ティフネスに与える影響を介入研究によって検討した報 告は，筆者らの文献渉猟の範囲では見当たらない．

以上のような背景から, 本研究は, 継続的な緑茶の摂 取が若年者の体脂肪と動脈スティフネスに及ぼす影響に
ついて検討することを目的とした，本研究では，継続的 な緑茶の摂取は, 若年者に扔ける体脂肪の減少と動脈入 ティフネスの低下を引き起こすという仮説を立て, 無作 為割り付け介入研究での検証を試みた。

\section{方法}

対象者 本研究では, 大学内において書面あるいは口頭 で学生に呼びかけ，98名の参加候補者をリクルートした。 参加基準は, 大学の運動部に所属して㧍らず，1回30分 以上の軽く汗をかく運動を週 2 回以上, 1 年以上行なっ て扮らず，慢性的かつ重篤な疾患を呈していない健常な 者とした，最終的に参加基準を満たし，研究への参加を 希望した健康な若年男女 57 名を対象者とした（Fig. 1). これらの参加者を年齢, 性別, Body mass index (BMI), CAVIが各群で同程度になるよう層化ブロックランダム 割り付け法によって, 対照群に 17 名, 介入 I 群に20名, 介入正群に 20 名に振り分けた，介入期間の途中，自己都 合で飲料の摂取を止めた 4 名の対象者を, 脱落者として 分析から除外した。したがって, 最終的な分析対象者は 53 名であり, 対照群が 14 名, 介入 I 群が19名, 介入II 群が 20 名であった，実験を開始するにあたって，全ての 参加者は, 本実験の目的や意義について十分説明を受け, それらを理解し実験参加に同意をした上で自主的に参加 した。な挹, 本研究の実験計画は, 大阪工業大学ライフ サイエンス実験倫理委員会の審査を受け, 承認を得た上 で実施した（承認番号2018-82）。

実験手順 本介入研究は，2019年 1 月から 2019年 3 月 にかけて実施された。測定当日，参加者には，測定の 2 時間前までに食事を済ませるよう指示した，最初に日 常の食事内容に関する質問紙調査を行い，参加者は30 分間の安静状態を保った。3 分間の安静後, 一定温度 $\left(22 \sim 24^{\circ} \mathrm{C}\right)$ に調整された室内に扔いて, 身体特性の評価 を行った. その後, 動脈スティフネスを評価し, 最後に, 安静時の代謝特性を評価した。本研究では介入期間を 4 週間に設定し， 4 週間後，再度同様の測定を行った。

身体特性 身長, 体重, 体脂肪, BMI，および腹囲を評 価した。体重や体脂肪（インピーダンス法）は, Body Fat Analyzer（TBF-110, タニタ社製）を用いて測定さ れた。なお，これらの測定は，対象者が素足の状態かつ 対象者ごとに介入前後の測定で同一の薄着を着用した状 態で行われた，腹囲は，立位姿勢で軽く息を吐かせ，臍 の位置で布製のメジャーを用いて測定された，腹囲の測 定は 3 回連続して行い, 平均值を代表值として用いた。 本研究室において, 各測定項目を異なる日に 2 回測定し た際の再現性を示す Coefficient of Variation (CV) は, $10 \%$ 未満である ${ }^{21-23)}$. 


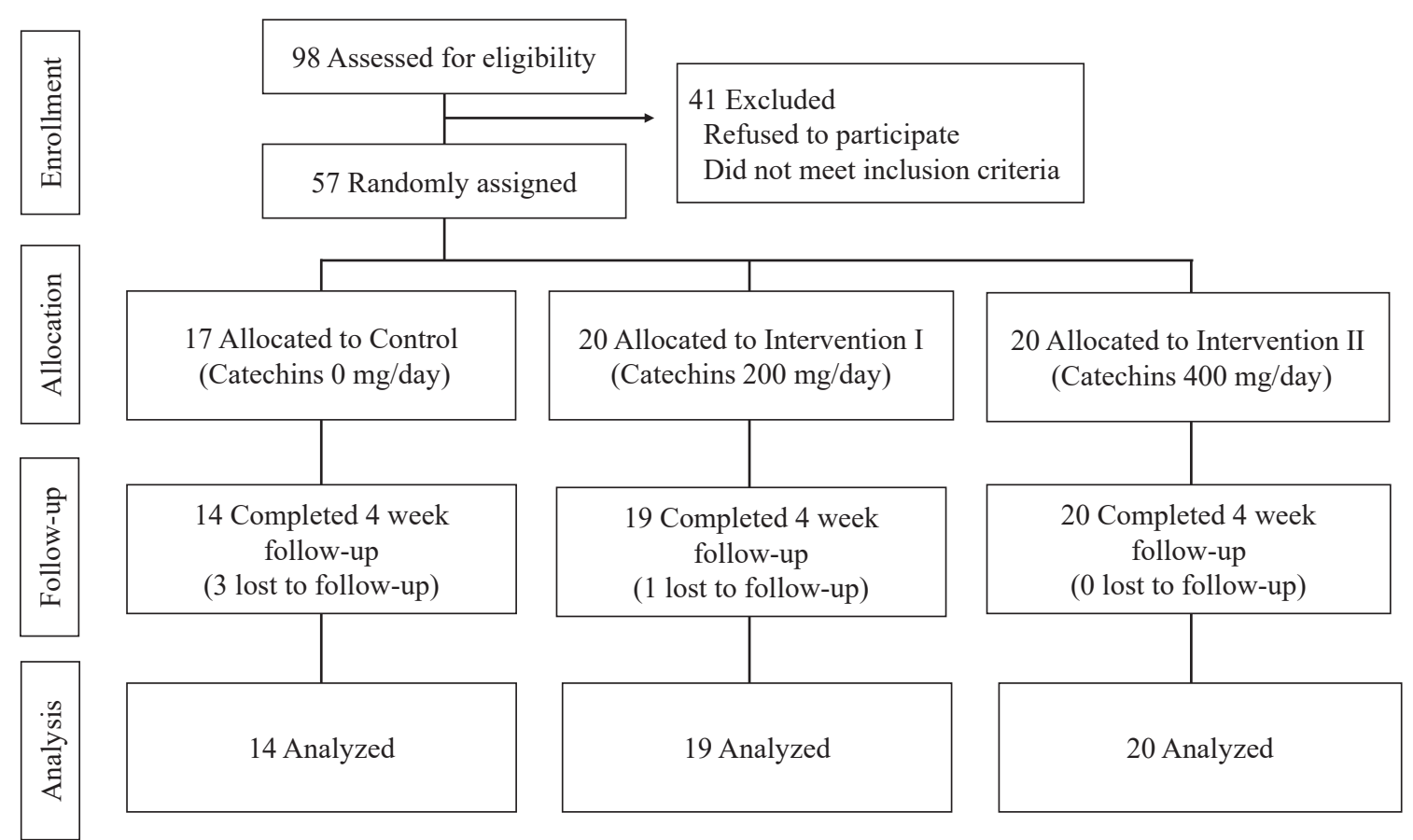

Fig. 1 Flow diagram of study participants.

動脈スティフネス 先行研究で用いられている方法を参 照し, 血圧脈波検査装置 (VS-1500AE/AN, フクダ電子 社製) を用いて ${ }^{24-26)}$, CAVI, Heart-Brachial PWV (hbPWV), Brachial-Ankle PWV (baPWV), Heart-Ankle PWV (haPWV) を動脈スティフネスの指標として計測 した。 心電困は両手首に装着した電極から，心音図は胸 骨左縁に装着したマイクロホンからそれぞれ記録した。 なお，心拍数が心電図波形における $\mathrm{R}-\mathrm{R}$ 間隔をもとに自 動的に算出された。 さらに，オシロメトリックセンサー が連結されているカフが参加者の左右上腕および両足首 に装着され，そこから，脈波と血圧が記録され，脈波伝 播時間とCAVI值が半自動的に算出された。先行研究の 式を参考に ${ }^{11)}, h b P W V$ とaPWV を算出する際の脈波 伝播距離を各対象者の身長を基に計算し, 計測された部 位に対応する脈波伝播時間で除すことで值を得た。また， haPWVは, 身長の入力で機械によって自動的に算出さ れた心臓から足首までの距離 $\mathrm{L}$ と対応する部位の脈波伝 播時間で除すことで算出した。本研究室における再現性 を示すCVは, 10\%未満である ${ }^{24-26) . ~}$

安静時の代謝特性 6 分間の座位姿勢時中に, 安静時の 代謝特性を評価した ${ }^{17,27)}$. 自動呼気ガス分析器（ポータ ブルガスモニター AR-10 Type-3, アルコシステム製)を 用い, ミキシングチャンバー法（チャンバー容量約 $2 \mathrm{~L}$ ) によって, 換気量 $(\dot{\mathrm{V} E})$, 酸素摂取量 $\left(\dot{\mathrm{V}} \mathrm{O}_{2}\right)$, 二酸化炭素 排出量 $\left(\dot{\mathrm{V} C O} \mathrm{CO}_{2}\right)$, 呼吸交換比 (RER) が15秒ごとに計測
された. 6 分間の計測データの最後の 2 分間の平均值を 各対象者の值としてその後の分析に使用した。また，以 下の式を用い, 糖質酸化量と脂質酸化量を算出した ${ }^{28)}$.

糖質酸化量 $=4.585 \times \dot{\mathrm{V}} \mathrm{CO}_{2}-3.226 \times \dot{\mathrm{V} O}{ }_{2}$

脂質酸化量 $=1.695 \times \dot{\mathrm{V} O} \mathrm{O}_{2}-1.701 \times \dot{\mathrm{V} C \mathrm{O}_{2}}$

なお, 代謝特性の測定のみデー夕欠損のあった 1 名を, 代謝特性の分析対象から除外し，結果を集計した。

食事内容アンケート 簡易型食事歴訪質問票（BDHQ） を用い，1日のエネルギー摂取量 (kcal), タンパク質摂 取量 $(\mathrm{g})$, 脂質摂取量 $(\mathrm{g})$, 炭水化物摂取量 $(\mathrm{g})$ を評 価した ${ }^{29}$ ) 。さらに、コーヒーと緑茶（本研究で配布され て摂取したものを含んで回答）の摂取状況および摂取量 を評価した，BDHQは過去 1 ケ月間に摂取した食品およ び飲料について，摂取した頻度や量の程度を尋ねる質問 票である。各参加者に, 過去 1 力月間の食事内容を思い 出させ, BDHQの質問項目に回答を記入させた ${ }^{17)}$ 。その 回答から, 専用ソフトを用い, 各栄養素の 1 日当たりの 推定の平均摂取量を算出した。 なお,コーヒーと緑茶の 摂取状況は, 各対象者が(1)毎日 4 杯以上, (2)毎日 2-3 杯以上, (3)毎日 1杯, (4)週 4-6 杯, (5)週 2-3 杯, (6)週 1杯, (7)週 1 杯未満, 8飲まなかった, の8段階の質問 から該当する番号を対象者が記述回答し，これを基にし て推定の摂取量を算出した。

歩数 対象者の保有する携帯電話の歩数計アプリ 
(iPhoneユーザー ヘルスケア, Android ユーザー ステッ プカウンター）を用い ${ }^{17.30)}$, 実験期間 4 週間の歩数を計 測し， 4 週間の介入期間を前半 2 週間と後半 2 週間に分 け，それぞれの参加者ごとに 1 日の平均值を算出した ${ }^{17)}$. その際, 先行研究にならい解析に有効な 1 日の歩数を 2,000歩以上と定義し，2,000歩未満はデータの集計から 除外した ${ }^{31-33)}$ 。なお，最終的な歩数の集計值には，アプ リの設定上の問題で值が計測できなかった 7 名の対象者 のデータを歩数分析対象からのみ除外した。

飲料の摂取介入 本研究では, 対照群の摂取する飲料に ミネラルウォーター（セブンプレミアムからだにうる 扔うアルカリ天然水, 株式会社伊藤園製) を用いた。 ネラルウォーターのラベルを剥がし, 対象者には「単な るミネラルウォーターではない健康有用成分が含まれて いる飲料」と伝え, 配布した。これに対し, 介入群には

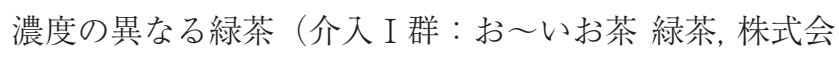
社伊藤園製, 介入II群：㧍〜い技茶濃い茶, 株式会社伊 藤園製）を配布した。いずれの群も市販されている飲料 を摂取させ, 各群の摂取量は 1 日 $500 \mathrm{~mL}$ とし, 茶カテ キン含有量は, 刘照群 $0 \mathrm{mg}$, 介入 I 群 $200 \mathrm{mg}$, 介入 II 群 $400 \mathrm{mg}$ であった，対象者には，1 日数回に分けて摂 取することを可として, 介入期間中, 毎日摂取させた。 なお，黍取し忘れがないよう，スマートフォンアプリの LINE（LINE株式会社）を用い, 参加者には飲料を摂取 したことを報告させた ${ }^{17)}$ ，なお，すべての対象者に配布 した飲料の摄取を除き, 緑茶とコーヒーを含む全ての飲 料, 食事, 運動などの生活習慣を普段通りに行うよう指 示をした。

統計処理 測定値は, 全て平均值士標準誤差で示した 各群の初期值の比較には，1元配置分散分析を用いた。 各試行のパラメーターの前後の比較には, 反復測定の 2 元配置分散分析を用いた．体脂肪率とRERの変化量の 差の比較には，1元配置分散分析を, トレンド性の評価 にはJonckheere-Terpstra testを用いた。さらに，変化 量の比較に有意差が認められた場合, 年齢, 性別, エネ ルギー撖取量の変化量, 初期值を共変量とした共分散分 析を行い, 各共変量で調整した上でも有意差が認められ るか検討を行った，な拉，ポストホックの多重比較の検 定にはすべてBonferroniの方法を用いた．また, コーヒー や緑茶の摂取状況のベースラインのスコアの比較には, Kruskal-Wallis testとScheffe法を, 各群の前後のスコ アの比較には, Wilcoxon signed-rank testを用いた。本 研究では, エクセル統計2015（社会情報サービス社製） とSPSS Statistics ver 25 (IBM SPSS Japan社製) を用 いて統計解析を行った. 危険率は全て 5 \%未満 $(\mathrm{P}<0.05)$ を有意とした。

\section{結果}

参加者の特性と介入に伴う変化に関するデー夕を Table 1に示した. 介入開始前の参加者の身体特性のべー スライン值に扔いて， 3 群の間で有意差は認められな かった. 2 元配置分散分析の結果, 身体特性の項目では, 体脂肪率で有意な交互作用が認められた。 介入前後の值 を比較すると, 対照群と介入 I 群の体脂肪率に有意な変 化はなかったが, 介入II群の体脂肪率に介入後にのみ有 意な低下が涊められた。しかし，体脂肪率を除くその他 の身体特性の項目に, 有意な変化は認められなかった。

介入前の各群の血圧や動脈機能のベースライン值の間 に有意差は認められなかった。動脈ステイフネスの指標 であるhbPWV, baPWV, haPWV, CAVI㧍よび血圧に おいて, 全ての群で, 介入後, 有意な変化は認められな かった（Table 1).

安静時の呼気ガスに関するデー夕を比較すると, 各群 のベースライン值の間に有意差は認められなかった，介 入後, 各群の $\dot{\mathrm{V} E}$ と $\dot{\mathrm{V}} \mathrm{O}_{2}$ に有意な変化はなかった，それ に対し, $\dot{\mathrm{V} C \mathrm{O}_{2}}$ では有意な交互作用が認められ，介入 II 群の $\dot{\mathrm{V} C \mathrm{CO}_{2}}$ のみ有意な低下が認められた。また, 統計上 有意な変化には至らなかったものの, 介入II群の RER に低下傾向が観察された。しかし, 対照群と介入I群の $\dot{\mathrm{V} C O}{ }_{2}$ と RERに有意な変化は認められなかった。ささらに, 本研究では, 糖質酸化量と脂質酸化量を算出したが全て の群で有意な変化は認められなかった（Table 1).

さらに, 介入期間中の食事と活動量の影響について検 討した. 2 元配置分散分析の結果, エネルギー捠取量と 脂質摂取量で群の主効果に有意差が認められ, 対照群 は, 介入 I 群や介入 II 群と比較し, 有意に高い值であっ た。しかし，炭水化物摂取量とタンパク質摂取量に群の 主効果は認められなかった。 また, タンパク質摂取量と 脂質摂取量に時間の主効果は認められなかったが，工ネ ルギー摂取量と炭水化物摂取量に有意な時間の主効果が 認められた。交互作用は認められなかったものの, 単純 主効果の有無（群ごとの介入前後の変化）を検討すると, 介入期間中に, 対照群と介入II群のエネルギー摂取量, および全ての群の炭水化物摂取量に有意な低下が認めら れた。なお，介入前から介入期間中へのエネルギー摂取 量の変化量を比較すると， 3 群の間に有意差は認められ ず，全ての群でお㧍よそ同程度のエネルギー摂取量の低 下であったことが示された，また，Fig. 2に，食事調査 の結果から, 介入期間の前と介入期間中のコーヒーおよ び緑茶の摂取頻度と推定摂取量についての比較結果を示 した。対照群では、コーヒーの摂取頻度と推定摂取量に 有意な変化は認められず, 介入期間中の緑茶の摂取頻度 に低下傾向, 緑茶の推定摂取量に有意な低下が認められ た。これに対し，介入 I 群のコーヒー摂取頻度と推定摂 
Table 1. Changes in physiological parameters of the participants before and after the intervention.

\begin{tabular}{|c|c|c|c|c|c|c|c|c|c|}
\hline \multirow[t]{2}{*}{ Variables } & \multicolumn{2}{|c|}{$\begin{array}{l}\text { Control group } \\
\qquad(n=14)\end{array}$} & \multicolumn{2}{|c|}{$\begin{array}{l}\text { Intervention I group } \\
\qquad(\mathrm{n}=19)\end{array}$} & \multicolumn{2}{|c|}{$\begin{array}{l}\text { Intervention II group } \\
\qquad(\mathrm{n}=20)\end{array}$} & \multicolumn{3}{|c|}{$\begin{array}{l}\text { ANOVA } \\
\text { P-value }\end{array}$} \\
\hline & Pre & Post & Pre & Post & Pre & Post & Group & Time & Interaction \\
\hline Participants (men/women) & $(11 / 3)$ & & $(13 / 6)$ & & $(16 / 4)$ & & & & \\
\hline Age, y & $21.2 \pm 0.3$ & - & $20.9 \pm 0.2$ & - & $21.1 \pm 0.2$ & - & & & \\
\hline Height, cm & $168.6 \pm 2.5$ & - & $167.1 \pm 1.6$ & - & $167.5 \pm 1.8$ & - & & & \\
\hline Body mass, $\mathrm{kg}$ & $61.2 \pm 3.0$ & $61.3 \pm 3.2$ & $57.6 \pm 1.9$ & $57.7 \pm 1.9$ & $59.2 \pm 2.5$ & $59.0 \pm 2.4$ & 0.605 & 0.847 & 0.524 \\
\hline Body mass index, $\mathrm{kg} / \mathrm{m}^{2}$ & $21.4 \pm 0.7$ & $21.5 \pm 0.8$ & $20.6 \pm 0.5$ & $20.6 \pm 0.6$ & $21.0 \pm 0.7$ & $20.9 \pm 0.7$ & 0.682 & 0.761 & 0.589 \\
\hline Body fat, $\%$ & $20.1 \pm 1.6$ & $20.4 \pm 1.7$ & $20.8 \pm 1.3$ & $20.6 \pm 1.3$ & $21.6 \pm 1.3$ & $20.6 \pm 1.3 *$ & 0.914 & 0.103 & 0.021 \\
\hline Lean body mass, $\mathrm{kg}$ & $48.9 \pm 2.5$ & $48.9 \pm 2.7$ & $45.4 \pm 1.4$ & $45.7 \pm 1.5$ & $46.2 \pm 1.7$ & $46.6 \pm 1.8$ & 0.474 & 0.211 & 0.591 \\
\hline Waist circumference, $\mathrm{cm}$ & $74.6 \pm 2.0$ & $73.3 \pm 1.9$ & $73.4 \pm 1.4$ & $73.0 \pm 1.5$ & $74.7 \pm 1.8$ & $74.1 \pm 1.8$ & 0.869 & 0.028 & 0.521 \\
\hline $\mathrm{HR}$, beats/min & $68 \pm 5$ & $66 \pm 4$ & $65 \pm 2$ & $64 \pm 2$ & $74 \pm 4$ & $69 \pm 3$ & 0.183 & 0.353 & 0.793 \\
\hline Systolic BP, mmHg & $118 \pm 2$ & $117 \pm 3$ & $120 \pm 3$ & $118 \pm 3$ & $124 \pm 2$ & $121 \pm 2$ & 0.335 & 0.063 & 0.641 \\
\hline Diastolic BP, mmHg & $68 \pm 2$ & $70 \pm 2$ & $71 \pm 1$ & $70 \pm 1$ & $72 \pm 1$ & $71 \pm 2$ & 0.349 & 0.956 & 0.113 \\
\hline Mean BP, mmHg & $85 \pm 2$ & $87 \pm 2$ & $87 \pm 2$ & $87 \pm 1$ & $90 \pm 2$ & $88 \pm 2$ & 0.407 & 0.906 & 0.187 \\
\hline hb-PWV (cm/s) & $333 \pm 7$ & $332 \pm 10$ & $337 \pm 7$ & $334 \pm 6$ & $339 \pm 7$ & $333 \pm 7$ & 0.930 & 0.317 & 0.832 \\
\hline ba-PWV (cm/s) & $1051 \pm 21$ & $1078 \pm 22$ & $1083 \pm 22$ & $1078 \pm 20$ & $1096 \pm 23$ & $1082 \pm 26$ & 0.726 & 0.811 & 0.297 \\
\hline ha-PWV (cm/s) & $604 \pm 11$ & $608 \pm 11$ & $613 \pm 8$ & $611 \pm 8$ & $621 \pm 9$ & $609 \pm 11$ & 0.783 & 0.531 & 0.381 \\
\hline CAVI & $6.1 \pm 0.2$ & $6.1 \pm 0.1$ & $6.2 \pm 0.1$ & $6.1 \pm 0.1$ & $6.1 \pm 0.1$ & $6.1 \pm 0.1$ & 0.945 & 0.844 & 0.956 \\
\hline Resting VE, L/min & $8.4 \pm 0.4$ & $8.4 \pm 0.5$ & $7.3 \pm 0.5$ & $7.5 \pm 0.4$ & $7.3 \pm 0.4$ & $6.8 \pm 0.4$ & 0.061 & 0.572 & 0.209 \\
\hline Resting $\mathrm{VO}_{2}, \mathrm{~L} / \mathrm{min}$ & $0.29 \pm 0.01$ & $0.27 \pm 0.02$ & $0.23 \pm 0.01$ & $0.24 \pm 0.01$ & $0.25 \pm 0.01$ & $0.24 \pm 0.01$ & 0.065 & 0.546 & 0.138 \\
\hline Resting $\mathrm{VCO}_{2}, \mathrm{~L} / \mathrm{min}$ & $0.24 \pm 0.01$ & $0.23 \pm 0.02$ & $0.19 \pm 0.01$ & $0.21 \pm 0.01$ & $0.21 \pm 0.01$ & $0.19 \pm 0.01 *$ & 0.133 & 0.355 & 0.038 \\
\hline Resting RER & $0.83 \pm 0.02$ & $0.84 \pm 0.04$ & $0.86 \pm 0.02$ & $0.85 \pm 0.02$ & $0.85 \pm 0.01$ & $0.81 \pm 0.01$ & 0.480 & 0.541 & 0.404 \\
\hline $\mathrm{CHO}$ oxidation, $\mathrm{g} / \mathrm{min}$ & $0.17 \pm 0.03$ & $0.16 \pm 0.05$ & $0.14 \pm 0.02$ & $0.16 \pm 0.03$ & $0.16 \pm 0.02$ & $0.12 \pm 0.01$ & 0.725 & 0.458 & 0.197 \\
\hline Fat oxidation, $\mathrm{g} / \mathrm{min}$ & $0.08 \pm 0.01$ & $0.08 \pm 0.02$ & $0.06 \pm 0.01$ & $0.06 \pm 0.01$ & $0.07 \pm 0.01$ & $0.08 \pm 0.01$ & 0.296 & 0.722 & 0.672 \\
\hline Total caloric intake, kcal/day & $2440 \pm 262$ & $2174 \pm 304 *$ & $1806 \pm 118$ & $1725 \pm 151$ & $1924 \pm 138$ & $1614 \pm 98 *$ & 0.047 & 0.004 & 0.371 \\
\hline Carbohydrate intake, g/day & $316.6 \pm 31.2$ & $245.8 \pm 37.1^{*}$ & $245.1 \pm 20.4$ & $220.5 \pm 15.9^{*}$ & $256.8 \pm 17.2$ & $216.1 \pm 14.2 *$ & 0.217 & $<0.001$ & 0.206 \\
\hline Fat intake, g/day & $78.6 \pm 10.8$ & $77.0 \pm 12.2$ & $55.7 \pm 3.4$ & $56.0 \pm 7.4$ & $55.9 \pm 4.1$ & $49.1 \pm 3.7$ & 0.021 & 0.371 & 0.584 \\
\hline Protein intake, g/day & $92.5 \pm 12.0$ & $91.2 \pm 13.8$ & $66.9 \pm 5.7$ & $70.8 \pm 11.4$ & $73.1 \pm 6.5$ & $61.9 \pm 5.1$ & 0.097 & 0.504 & 0.307 \\
\hline
\end{tabular}

$\mathrm{HR}$, heart rate; BP, blood pressure; hbPWV, heart-brachial pulse wave velocity; baPWV, brachial-ankle pulse wave velocity; haPWV, heart-ankle pulse wave velocity; CAVI; cardio-ankle vascular index; $\dot{V E}$, minute expired ventilation; $\dot{\mathrm{VO}}_{2}$, oxygen uptake; $\dot{\mathrm{V} C O}$, carbon dioxide output; RER, Respiratory exchange ratio; Pre, before intervention; Post, after intervention; ${ }^{*} \mathrm{P}<0.05$ vs. each pre. Data are expressed as means \pm SE. 
取量に低下傾向，介入II群のコーヒー摂取頻度と推定摂 取量に有意な低下が認められた。また，介入 I 群と介入 II 群の緑茶摂取頻度および推定摂取量に有意な増大が認 められた。な掞, 介入 I 群と介入II群の緑茶摂取頻度の 回答の最頻值は,「(2)毎日 $2-3$ 杯」の回答であった。一 方, 介入期間に㧈ける歩数の值は, 対照群で前半 2 週間 $7744 \pm 388$ 歩/日, 後半 2 週間 $7616 \pm 625$ 歩/日, 介入 I 群
で $8502 \pm 587$ 歩/日，7581 \pm 587 歩/日，介入 II群で $7971 \pm$ 530歩/日, 7596 478 歩/日であった. 各群の歩数の值の 間に有意差は認められず，全ての群に押いて介入期間中 の有意な変化も認められなかった.

次に， 3 群の介入前から介入後への体脂肪率と RER の変化量を比較した（Fig. 3). 体脂肪率の変化量では,

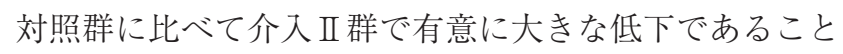

A

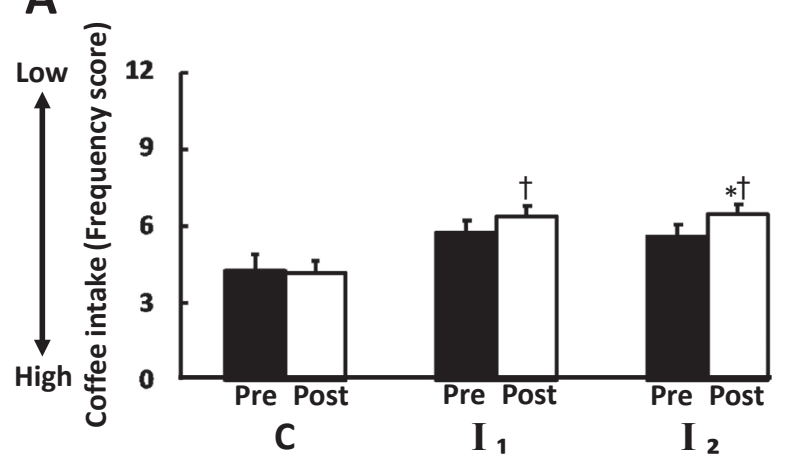

C

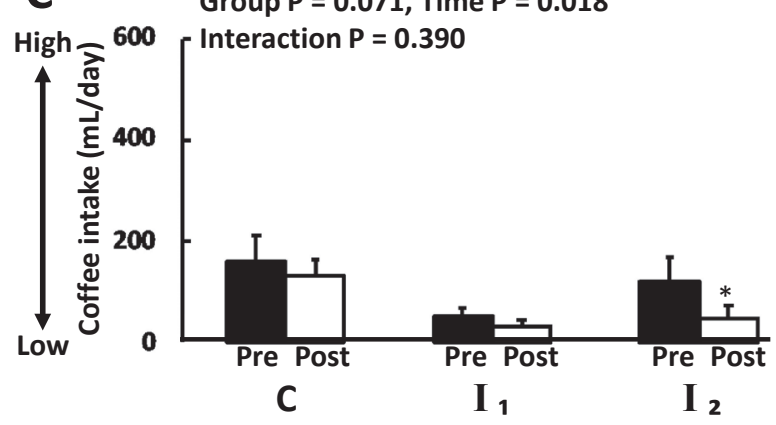

B

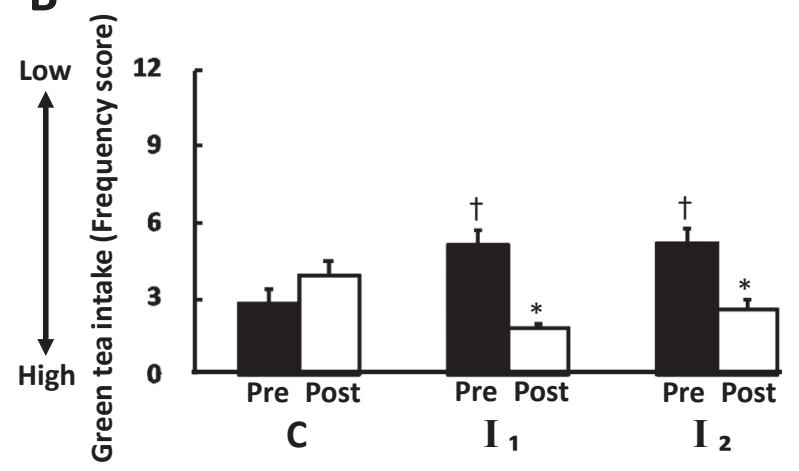

D Group $P=0.817$, Time $P=0.005$

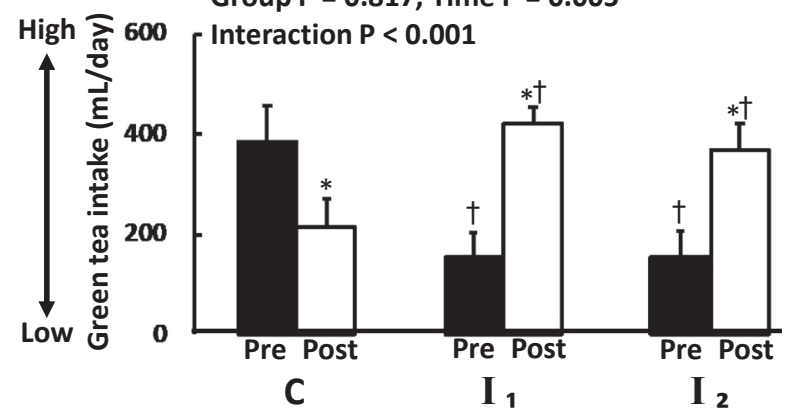

Fig. 2 Comparison of coffee (A, C) and green tea (B, D) intake before and after intervention.

$\mathrm{C}$, control group; $\mathrm{I}_{1}$, Intervention $1 ; \mathrm{I}_{2}$, Intervention 2; Pre, before intervention; Post, after intervention; ${ }^{\mathrm{P}}<0.05$ vs. before intervention within the same group; $\uparrow \mathrm{P}<0.05$ vs. control group at the same time point. Data are expressed as means \pm SE.

A

$$
\begin{aligned}
\text { ANOVA } P & =0.021 \\
\text { Trend } P & =0.006
\end{aligned}
$$

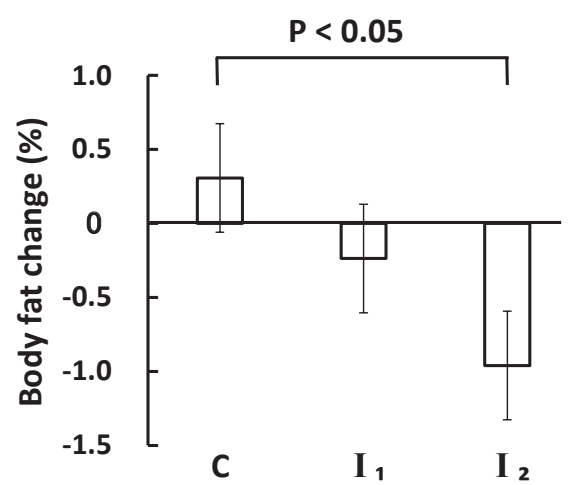

B

ANOVA $P=0.392$

Trend $P=0.040$

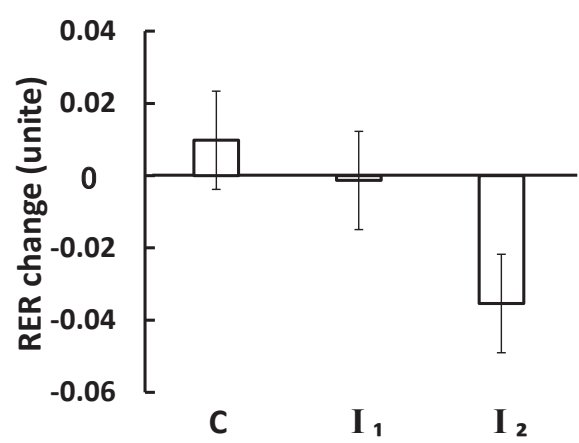

Fig. 3 Comparison of changes in body fat (A) and RER (B).

C, control group; $\mathrm{I}_{1}$, Intervention $1 ; \mathrm{I}_{2}$, Intervention 2 ; RER, respiratory exchange ratio. Data are expressed as means \pm SE. 
が示された，さらに，体脂肪率の変化量に有意な減少の トレンドが認められた。すなわち，カテキンの摂取量の 増大に伴い体脂肪率の低下量が増大寸る量一反応関係が 観察されたことを示すものである。一方, RERの変化量 では，各群の值の間に有意な差は認められなかったが, 体脂肪と同様，有意な減少のトレンドが認められた。す なわち, カテキン摂取量の増大に伴い, RERの低下量 が増大する量一反応関係が観察されたことを意味してい た。なお，体脂肪率に扔いて，年齢，性別，エネルギー 摂取量の変化量, および初期值を共変量とした共分散分 析を行ったところ, これらの項目を統計的に調整した上 でも分散分析の結果と同様，対照群に比べて介入 II 群 の変化量は，有意に大きな低下であることが示された $(\mathrm{P}<0.05)$.

\section{考察}

本研究では, 継続的な緑茶の摂取が若年者の体脂肪と 動脈スティフネスに及ぼす影響について検討した。そその 結果，1）介入 II 群でのみ体脂肪率に有意な低下が認め られた, 2 ) 各群の体脂肪率の変化量と RERの変化量に, 有意な減少のトレンドが認められた，3）全ての群にお いてPWVとCAVIに有意な変化は認められなかった, ことが示された。

本研究は, 参加者の負担や苦痛を軽減するため, 介入 期間中の配布飲料を除き，コーヒーと緑茶の摂取を普段 通り継続するよう指示していた。したがって, 本研究は, 日常的な生活に, 緑茶もしくは濃い茶の摂取量を増大さ せる介入が体脂肪と動脈スティフネスに与える影響を検 証していたことになる。 そこで, 介入に伴うコーヒーや 配布飲料以外の緑茶の摂取の影響を検討した。対照群で は, 介入期間中のコーヒーや緑茶の自由摂取量は, 介入 開始前と同等, もしくは少なかったことから, 日常生活 時のコーヒーや緑茶の摂取量増大それ自体が対照群の体 脂肪と動脈スティフネスの変化に影響を与えていた可能 性は極めて低かったと考えられる。 これに対し, 介入 I 群でコーヒー摂取量の低下傾向, 介入II群でコーヒー摂 取量の有意な低下が観察されたことから, 対象群と同様, 少なくとも介入 I 群と介入II群の体脂肪と動脈スティフ ネスの変化に日常生活中のコーヒー摂取量増加それ自体 が影響を与えていた可能性は低いと考えられる。また, 本研究のコーヒーや緑茶の推定摂取量は, 対象者が回答 した 8 段階の摂取頻度から換算された值であり，実際の 摂取容量を厳密に推定できてはいないと考えられるが, 介入 I 群と介入 II 群では, 介入に伴い緑茶の摂取量が増 大していた。 しかし, 回答の最頻值が回答可能な最大量 ではなかったため, 日常での自由摂取量と介入に伴う配 布による摂取の合計で最大量に達していなかったと考え られ，日常生活中での㧍茶の摂取量が介入に伴う配布容
量以上に顕著に増大していた可能性は低かったと推測さ れた，以上のことから，本研究は，飲料摂取の介入研究 として研究デザイン上の制限を有するものであったが, 本結果に対する配布飲料以外のコーヒーや緑茶の摂取量 増大の影響は少なかったと考えられた，

これまで，ヒトを対象とした若年標準体形者に対する 緑茶やカテキン摂取が体脂肪に与える影響について検討 されて扮らず，本研究では，その効果を検討した，その 結果，カテキン類を濃い茶によって $400 \mathrm{mg} / \mathrm{day}$ 摂取し た介入II群でのみ有意な体脂肪の低下が認められた。し かし, 本研究では, 対象者全体として食事摂取量の減少 が観察され, さらに, 本研究の体組成の評価は, インピー ダンス法によって行われた。 インピーダンス法は，実質 的に 2 組成モデルであり, 電気抵抗から水中体重秤量法 などによって求めた除脂肪体重を推定し，そこから四則 演算によって体脂肪率を算出していることから，その妥 当性や再現性について議論されてきた ${ }^{34)}$. 本研究では, 介入後, いずれの群に打いても, 除脂肪体重に有意な変 化は認められなかったが，介入 I 群と介入II群で若干の 増大傾向が観察された。ささらに，介入II群でのみ体脂肪 率と体脂肪量に有意な低下が認められていたが，体脂肪 の変化は $-1.0 \pm 0.3 \%(-0.6 \pm 0.2 \mathrm{~kg})$ であり, 先行研究と 比較しても，期間が 4 週間ということもあり，大きな変 化ではなかった ${ }^{7)}$ 。したがって, これらの結果は, 全体 的な食事摄取量の減少やインピーダンス法による体脂肪 率の測定誤差の影響が本研究結果に大きな影響を及ぼし ている可能性を完全には排除できない，その一方で，有

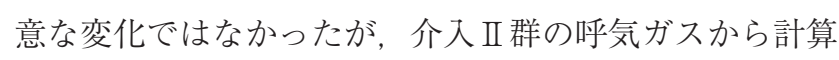
された脂質酸化量が 3 群の中で唯一増大 $(0.01 \mathrm{~g} / \mathrm{min})$ していた。この変化が介入期間中を通じて生じていた と仮定すると, 約 $0.4 \mathrm{~kg}(0.01 \mathrm{~g} / \mathrm{min} \times 60$ 分 $\times 24$ 時間 $\times$ 28-30日）の体脂肪の減少が得られると推計可能であり, 本結果で得られている実測值と扮扔よそ一致していると 考えることもできる，さらに，本研究では，各群の体脂 肪率の変化量に有意な減少のトレンドが認められ，カテ キン類摂取量の増大に伴い, 濃度依存的に体脂肪率の低 下が大きくなることが示された，また，同時にRERの変 化量にも有意な減少のトレンドが認められ, 茶カテキン 摂取量の増大に伴い, 安静時の代謝特性が脂質を基質と してエネルギー産生を行う方向にシフトしていたことも 示された。したがって, これらのデー夕は, 単純に全体 的な食事摂取量の減少とインピーダンス法による体脂肪 率の測定誤差の影響のみで本結果を解釈できないことも 意味するものである。また，本研究では，年齢や性別， 体脂肪の初期值に加え, エネルギー摂取量を補正因子と して投入した上でも，介入II群の体脂肪減少は，対照群 よりも有意に大きく, 補正前と同様の結果が得られるこ とも確認した，以上の結果から，本研究には，全体的な 
食事摂取量の減少やインピーダンス法による測定精度と いった本研究を解釈する上で重要な限界点が存在するも のの, 4 週間の継続的な濃い茶によるカテキン摂取は, 若年標準体形者の体脂肪を有意に低下させる可能性が示 唆された.

本研究の緑茶摂取に伴う脂質代謝の立進や体脂肪の低 減は, どのような生理学的機序によって生じたのだろう か. 先行研究では, カテキンをマウスに経口投与すると, アセチルCoAカルボキシラーゼのリン酸化と AMPactivated protein kinase (AMPK) 活性が増加すること が報告されている ${ }^{6.35)}$ ，実際，本研究でも， $\mathrm{VCO}_{2}$ とRER のデータが介入II 群の脂質代謝の方進を示唆している. したがって, 1つの可能性として, 本研究に扔いても AMPK 活性の増大に伴う脂質酸化の増大が生じていた のかもしれない，また，別の観点から考察すると，コー ヒ一の摂取は, 脂質代謝を促進させる可能性が報告され ており ${ }^{27)}$, 本研究の緑茶にもコーヒーの主たる成分で あるカフェインが含まれている。しかし，本研究に扔け る介入 I 群と介入II群のカフェイン含有量は，それぞれ $65 \mathrm{mg}$ と $95 \mathrm{mg}$ であり, 一般的なコーヒーの含有量（約 $300 \mathrm{mg}$ ）と比較してもわずかな差である. したがって, 介入に伴い配布した緑茶に含まれるカフェインが，介入 II 群の体脂肪低下を引き起こした主な要因とは考えにく い. しかしながら, 本研究の結果からのみでは, 詳細な 生理学的機序は明らかではないため, 今後の検討が必要 なところである。

次に, 緑茶の摂取が動脈スティフネスに及ぼす影響に ついて検討した. 先行研究より, 若年者が高カカオチョ コレート（カカオポリフェノール508 mg）を 4 週間摂取 すると, CAVIやPWVで評価した動脈スティフネスが有 意に低下したことが報告されている ${ }^{17)}$.また, メタボリッ クシンドロームを呈する者がブルーベリーを 6 カ月間摂 取すると，血管内皮機能の改善が認められている ${ }^{36)}$ 。し かし, 同じポリフェノールであり, フラボノイド類のフ ラバノール（カテキン）類に該当する緑茶カテキンの摂 取が動脈スティフネスに与える影響はこれまで明らかで はなかった，本研究では，動脈スティフネスの指標とし て, hbPWV, baPWV, haPWV, CAVIを用いたが,い ずれの指標においても全ての群で有意な変化は認められ なかった，さらに，本研究では，血圧や心拍数にも有意 な変化は認められなかった。したがって, 特に若年者に 掞いて, 緑茶カテキンの摂取は, 動脈スティフネスを低 下させないことが示された。

高カカオチョコレートやブルーベリーとは異なり, 緑 茶カテキン摂取は動脈スティフネスを変化させない理由 を考察したい. 第 1 に, 今回の茶カテキン摂取では, カ テキン類が体内で効果を発揮するためには量が不足して いた可能性がある。しかし, 高カカオチョコレートの研
究で摂取したカカオポリフェノール量と本研究の茶カテ キン量は扮扮よそ同等になるよう設定していた。また， 介入 II 群で体脂肪率に有意な低下が認められ, 体脂肪率 やRERの変化量に, 濃度依存的に減少トレンドが認めら れた点を考慮すると, カテキン摂取量が極端に少なかっ た可能性は非常に低いと考えられる。第 2 に, ポリフェ ノールは, 化学構造からいくつかの種類に分けられる ${ }^{4,5)}$. 高カカオチョコレートやダークチョコレートに含まれる 主たるポリフェノールは, フラバノール類のエピカテキ ンであり,ブルーベリーなどに含まれるのはアントシア ニンである ${ }^{4,5)}$.これに対し，緑茶にはエピカテキン等も 含まれてはいるものの, 主に含まれているポリフェノー ルは, 同じフラボノイド類のフラバノール類ではあるが, エピガロカテキンガレートである ${ }^{4-6,9)}$. フラボノイド類 の腸管吸収機構はそれぞれのフラボノイド類により特徵 があり，エピガロカテキンガレートは腸管から吸収され にくいフラボノイド類であるが, ヒト血中に代謝を受け ない未変化のものがみられることから, 代謝されにくい フラボノイド類でもあると考えられている37)。したがっ て，上述したわずかな化学構造の違いによって体内での 吸収のしやすさや反応のしやすさ等が異なる可能性があ $\eta^{4,5,38)}$ ，緑茶中に含まれる茶カテキンは動脈スティフネ 又を低下させるような抗酸化作用を有していない可能性 が考えられる ${ }^{39)}$. 第 3 に, 先行研究では, 喫煙者が継続 的に緑茶（カテキン類の含有量 $580 \mathrm{mg}$ ）を摂取すると, 血管内皮機能が増大し, 動脈機能が改善することが報告 されている ${ }^{40,41)}$. したがって, 1 つの可能性として, 緑 茶カテキンも動脈伸展性を高める効果をわずかながら有 して㧍り，喫煙者など健常者よりも血管内皮の状態が悪 化しているような対象者には効果を発揮するものの, 高 カカオチョコレートなどの場合と比較し ${ }^{17)}$, 健常な若年 者の動脈スティフネスを改善させるほどの強い効果を有 していないのかもしれない. 実際, 疫学的な横断研究で も緑茶摂取量と動脈スティフネスの間に有意な関連性は 認められていない20). 以上のことから, 茶カテキンは, ポリフェノールのフラボノイド類に分類される成分では あるが, カカオポリフェノールとは異なり, 少なくとも 健常若年者の動脈スティフネスを低下させるほどの強い 作用を有していないと考えられる。 今後, 異なる対象者 や異なるポリフェノール成分を用いたさらなる研究が期 待されるところである。

高瀬らの研究では, 肥満女性に茶カテキン $539.7 \mathrm{mg} /$ day 12 週間摂取させ, 体重 (介入前: $67.2 \pm 6.6 \mathrm{~kg}$, 介入 後: $64.3 \pm 6.7 \mathrm{~kg}$ ) や腹部脂肪面積（介入前： $405.8 \pm 49.4$ $\mathrm{cm}^{2}$, 介入後: $391.4 \pm 51.4 \mathrm{~cm}^{2}$ ) が有意に低下している(こ の研究のみエラーバーが標準偏差で示されている $)^{8)}$. 高 妻らの研究では, 肥満女性に茶カテキン $540 \mathrm{mg} / \mathrm{day}$ を 12 週間摂取させ, 体重 (介入前: $63.42 \pm 0.79 \mathrm{~kg}$, 介入後: 
$60.91 \pm 0.81 \mathrm{~kg}$ ) や体脂肪率 (介入前: $35.75 \pm 0.63 \%$, 介入 後: $32.28 \pm 0.55 \%$ ), 腹部脂肪面積 (介入前: $335.5 \pm 11.8$ $\mathrm{cm}^{2}$, 介入後: $320.4 \pm 11.5 \mathrm{~cm}^{2}$ ) が有意に低下している7 . Kobayashi et al.の研究では, 肥満者に 12 週間, 茶カテ キン（特にガレート型カテキン）を $279.5 \mathrm{mg} / \mathrm{day}$ 摂取さ せると体重 (介入前: $72.5 \pm 1.4 \mathrm{~kg}$, 介入後: $71.9 \pm 1.4 \mathrm{~kg}$ ) や腹部脂肪面積 (介入前: $324.3 \pm 8.2 \mathrm{~cm}^{2}$, 介入後: $299.7 \pm$ $\left.8.8 \mathrm{~cm}^{2}\right)$ が有意に低下している9). さらに, Kajimoto et al. の研究では, 平均年齢 $43 \pm 12$ 歳の健常者に茶カテキ ン類 $665.9 \mathrm{mg} / \mathrm{day}$ ⿸ 12 週間摂取させると体重（介入前: $68.5 \pm 1.1 \mathrm{~kg}$, 介入後: $67.8 \pm 1.1 \mathrm{~kg}$ ) や腹部脂肪面積 (介 入前: $293 \pm 7 \mathrm{~cm}^{2}$, 介入後: $285 \pm 8 \mathrm{~cm}^{2}$ ) が有意に低下 することを報告している ${ }^{10)}$.また, Kobayashi et al.や Kajimoto et al.の研究では, 抒打む称 4 週間後には体重 の変化が引き起こりはじめることが示されている ${ }^{9,10)}$. これらの報告に対し, 本研究では, 若年健常者に, 茶力 テキン $400 \mathrm{mg} / \mathrm{day}$ を 4 週間摂取させ, 体重に有意な変 化は認められず（介入前: $59.2 \pm 2.5 \mathrm{~kg}$, 介入後: $59.0 \pm$ $2.4 \mathrm{~kg}$ ), 体脂肪の低下のみが認められた（介入前: 21.6 $\pm 1.3 \%$, 介入後: $20.6 \pm 1.3 \%)$. したがって, これらの知 見を総合すると, 茶カテキン摂取の介入研究はほとんど が日本人を対象に実施されて扮り, 肥満者と健常者でほ ぼ同様の応答が報告されていると考元られる。すなわ ち，お拉むね茶カテキンを，4週間から 12 週間，1日に 400-500 mg/day 摂取することで体重や脂肪低隇効果が 期待できる可能性が示唆された。 また, 限られたデー夕 ではあるものの, 体重や体脂肪の初期值が高い場合の方 が茶カテキンの体重・体脂肪低減効果が得られやすい傾 向を示すものであった，今後，茶カテキンの摂取を活用 したさらなる減量プログラムの発展が期待されるところ である。

本研究にはいくつかの重要な限界点が含まれている. 第 1 に, 本研究では血液検査を実施できなかったことで ある、特に、コレステロールや遊離脂肪酸, 血糖值に対 する効果が検討できなかったこと, 緑茶の効果を検証す るに際して対象者の血中のカテキン濃度を評価できてい ないことから, 議論の余地がある. 第 2 に, 本研究で は, 体脂肪率や体脂肪量が有意に減少したにもかかわら ず，体重や BMI，腹囲に有意な変化が認められなかっ た、インピーダンス法による測定精度の問題もあり, 現 在, この点について詳細な理由は不明であるが, 介入 後, 対照群と介入 I 群の体重が若干高い值に変化してい た一方, 介入II群の体重は若干低い值に変化していた。 本研究は 4 週間という比較的短期の介入であったことか ら, 若年標準体形者に食品摂取のみで身体組成の項目す べてに明確な差を引き起こすためには介入期間が不足し ていた可能性が考元られ, 今後, より長期の介入研究の 実施が期待されるところである，第 3 に，食事において
は，全ての群において，エネルギー搙取量の有意な減少 が認められた，本研究では，エネルギー摂取量の変化の 影響などを統計上補正した上でも介入II群の体脂肪減少 は, 対照群よりも有意に大きく, 補正前と同様の結果が 得られることを確認している. しかし, 本介入研究は, 主に 2 月から 3 月にかけて実施されたものであるが, 若 年大学生にとって, 授業期間から長期休みの期間に変更 となる時期であり，生活習慣などがやや乱れ，全体的に 若干食事量や食事回数が低下していた可能性が考元られ たが, 本研究でそれを明確に示す客観的なデー夕は取得 できていない，今後，以上の点を考慮したより長期間に わたる詳細な検討が必要であるだろう。

\section{結 論}

本研究では, 継続的な緑茶の摂取が若年者の体脂肪と 動脈スティフネスに及ぼす影響について検討した。 その 結果, 濃い茶 (茶カテキン $400 \mathrm{mg}$ ) を摂取させた介入II 群でのみ体脂肪率に有意な低下が認められた。ささらに, 各群の体脂肪率の変化量と RERの変化量に, 有意な減 少のトレンドが認められ,カテキン摂取量の増大に伴い, 体脂肪率や RERの低下量が増大寸る量一反応関係が観察 された。しかしながら, 全ての群に执いて, 動脈スティ フネスの指標であるPWV とCAVIの結果に有意な変化 は認められなかった。

したがって, 本研究の結果から, 4 週間の継続的な緑 茶 (特に茶カテキン $400 \mathrm{mg}$ を含有する濃い茶)の摂取は, 若年者であっても体脂肪を有意に低下させる可能性が示 唆された。しかし, 特に若年者の動脈スティフネスに対 する継続的な緑茶摂取の効果は認められないことが示さ れた。ただし，本研究には，結果を解釈する上での研究 方法上の制限がいくつか含まれることから，今後のさら なる長期的かつ詳細な研究の実施が必要であろう.

\section{謝 辞}

本研究に参加並びにご協力いただきました皆様に厚く御 礼申し上げます。また，多大なるご助言をいただきました 大阪工業大学工学部総合人間学系教室健康体育研究室の中 村友浩先生と石道峰典先生に心から感謝申し上げます.

\section{利益相反自己申告 :}

申告すべき該当事項はなく, 共著者全員が利益相反はない.

\section{著者貢献}

SK と NM, MNが研究デザインとプロトコルを構想した。 SK と MNが実験の実施, 主たるデー夕分析を行った. SK, $\mathrm{CN}, \mathrm{NO}, \mathrm{NM}, \mathrm{MN}$ がデータの解釈を行った. SKと MNが 草稿を担当した，全ての著者が原稿を批判的にレビューし， 修正し，投稿を承認した。 


\section{参考文献}

1) Lin X, Zhang I, Li A, Manson JE, Sesso HD, Wang L, Liu S. Cocoa flavanol intake and biomarkers for cardiometabolic health: A systematic review and metaanalysis of randomized controlled trials. J Nutr 146: 2325-2333, 2016.

2) West SG, McIntyre MD, Piotrowski MJ, Poupin N, Miller DL, Preston AG, Wagner P, Groves LF, SkulasRay AC. Effects of dark chocolate and cocoa consumption on endothelial function and arterial stiffness in overweight adults. Br J Nutr 111: 653-661, 2014.

3) Ludovici V, Barthelmes J, Nagele MP, Enseleit F, Ferri C, Flammer AJ, Ruschitzka F, Sudano I. Cocoa, blood pressure, and vascular function. Front Nutr 4: 36, 2017.

4）越阪部奈緒美：ポリフェノールパラドックス 生体利用 性と機能性の矛盾, 化学と生物, 54: 726-731, 2016.

5）寺尾純二, 芦田均: 機能性ポリフェノール, 化学と生物, 44: 688-698, 2006.

6) Murase T, Haramizu S, Shimotoyodome A, Tokimitsu I, Hase T. Green tea extract improves running endurance in mice by stimulating lipid utilization during exercise. Am J Physiol Regul Integr Comp Physiol 290: R1550-1556, 2006.

7）高妻和哉, 千宒映郎, 星野栄一, 片岡 潔, 森 建太, 長谷 正, 桂木能久, 時光一郎, 中村治雄 : 肥満男女に対する力 テキン含有飲料摂取の効果, Prog Med 25: 1945-1957, 2005.

8）高瀬秀人, 長尾知紀, 大塚和弘, 目黑真一, 小御門雅典, 時 光一郎：高濃度茶カテキンの継続摂取が内臓脂肪型肥 満女性の内臟脂肪抒よびメタボリックシンドロームリ スクに及ほす影響, Jpn Pharmacol Ther (薬理と治療), 36: 237-245, 2008.

9) Kobayashi M, Kawano T, Ukawa Y, Sagesaka YM, Fukuhara I. Green tea beverages enriched with catechins with a galloyl moiety reduce body fat in moderately obese adults: a randomized double-blind placebocontrolled trial. Food Funct 7: 498-507, 2016.

10) Kajimoto O, Kajimoto $Y$, Yabune M, Nakamura T, Kotani K, Suzuki Y, Nozawa A, Nagata K, Unno T, Mitane Sagesaka Y, Kakuda T, Yoshikawa T. Tea catechins with a galloyl moiety reduce body weight and fat. J Health Sci 51: 161-171, 2005.

11) Yamashina A, Tomiyama H, Takeda K, Tsuda H, Arai T, Hirose K, Koji Y, Hori S, Yamamoto Y. Validity, reproducibility, and clinical significance of noninvasive brachial-ankle pulse wave velocity measurement. $H y$ pertens Res 25: 359-364, 2002.

12) Shirai K, Hiruta N, Song M, Kurosu T, Suzuki J, Tomaru T, Miyashita Y, Saiki A, Takahashi M, Suzuki K, Takata M. Cardio-ankle vascular index (CAVI) as a novel indicator of arterial stiffness: theory, evidence and perspectives. $J$ Atheroscler Thromb 18: 924-938, 2011.

13) Nishiwaki M, Kurobe K, Kiuchi A, Nakamura T, Matsumoto N. Sex differences in flexibility-arterial Stiffness relationship and its application for diagnosis of ar- terial stiffening: A cross-sectional observational study. PLoS One 9: e113646, 2014.

14) Nishiwaki M, Ogawa N, Nanayama C, Matsumoto N. Characteristics of blood pressure, arterial stiffness, and physical fitness in older adult Japanese community dwellers: a cross-sectional observational study. J Phys Fitness Sports Med 8: 187-193, 2019.

15) Laurent $S$, Boutouyrie P. Recent advances in arterial stiffness and wave reflection in human hypertension. Hypertension 49: 1202-1206, 2007.

16) Vlachopoulos $C$, Aznaouridis $K$, Terentes-Printzios D, Ioakeimidis N, Stefanadis C. Prediction of cardiovascular events and all-cause mortality with brachialankle elasticity index: a systematic review and metaanalysis. Hypertension 60: 556-562, 2012.

17) Nishiwaki M, Nakano Y, Matsumoto N. Effects of regular high-cocoa chocolate intake on arterial stiffness and metabolic characteristics during exercise. Nutrition 60: 53-58, 2019.

18) Baba S, Osakabe N, Yasuda A, Natsume M, Takizawa T, Nakamura T, Terao J. Bioavailability of (-)-epicatechin upon intake of chocolate and cocoa in human volunteers. Free Radic Res 33: 635-641, 2000.

19) Dower JI, Geleijnse JM, Gijsbers L, Zock PL, Kromhout D, Hollman PC. Effects of the pure flavonoids epicatechin and quercetin on vascular function and cardiometabolic health: a randomized, double-blind, placebo-controlled, crossover trial. Am J Clin Nutr 101: 914-921, 2015.

20) Uemura H, Katsuura-Kamano S, Yamaguchi M, Nakamoto M, Hiyoshi M, Arisawa K. Consumption of coffee, not green tea, is inversely associated with arterial stiffness in Japanese men. Eur J Clin Nutr 67: 11091114, 2013.

21) Nishiwaki M, Kuriyama A, Ikegami $Y$, Nakashima N, Matsumoto N. A pilot crossover study: effects of an intervention using an activity monitor with computerized game functions on physical activity and body composition. J Physiol Anthropol 33: 35, 2014.

22) Nishiwaki M, Nakashima N, Ikegami Y, Kawakami R, Kurobe K, Matsumoto N. A pilot lifestyle intervention study: effects of an intervention using an activity monitor and Twitter on physical activity and body composition. J Sports Med Phys Fitness 57: 402-410, 2017.

23) Nishiwaki M, Fujibayashi M, Nanayama C, Ogawa N, Itakura I, Matsumoto N. Increasing levels of daily physical activity for arterial stiffness reduction in older women: a community-based pilot study. J Sports Med Phys Fitness 58: 1701-1709, 2018.

24) Nishiwaki M, Yonemura H, Kurobe K, Matsumoto N. Four weeks of regular static stretching reduces arterial stiffness in middle-aged men. Springerplus 4: 555, 2015.

25) Nishiwaki M, Kora N, Matsumoto N. Ingesting a small amount of beer reduces arterial stiffness in healthy humans. Physiol Rep 5: 2017. 
26) Nishiwaki M, Takahara K, Matsumoto N. Arterial stiffness in young adult swimmers. Eur J Appl Physiol 117: 131-138, 2017.

27) Kurobe K, Nakao S, Nishiwaki M, Matsumoto N. Combined effect of coffee ingestion and repeated bouts of low-intensity exercise on fat oxidation. Clin Physiol Funct Imaging 37: 148-154, 2017.

28) Manetta J, Brun JF, Perez-Martin A, Callis A, Prefaut $\mathrm{C}$, Mercier J. Fuel oxidation during exercise in middleaged men: role of training and glucose disposal. Med Sci Sports Exerc 34: 423-429, 2002.

29) Kobayashi S, Honda S, Murakami K, Sasaki S, Okubo H, Hirota N, Notsu A, Fukui M, Date C. Both comprehensive and brief self-administered diet history questionnaires satisfactorily rank nutrient intakes in Japanese adults. J Epidemiol 22: 151-159, 2012.

30）西脇雅人, 松本直幸: ポケモン GOのプレイが日常歩数 に及ぼす影響 一日本人男子大学生を対象とした後万向 き観察研究一,体力科学, 67: 237-243, 2018.

31）西脇雅人, 中嶋名菜, 池上由美, 川上諒子, 黒部一道, 松本 直幸：活動量計と Twitterを併用した生活介入が身体 活動量に与える影響 一無作為割り付け介入試験一, 体力 科学, 62: 293-302, 2013.

32）西脇雅人, 木内敦詞, 中村友浩：インターネット依存と 歩数の関係 - 男子大学 1 年生を対象とした横断研究体力科学, 63: 445-453, 2014.

33）西脇雅人, 木内敦詞, 中村友浩：過去10年間にわたる歩 数の低下とその理由に関する検討 - 男子大学 1 年生 を対象とした連続横断研究一, 体力科学, 63: 231-242, 2014.

34）田中喜代次, 中田由夫：減量しながら筋肉量抢よび基礎 代謝量を高めることは可能か? 体力科学, 66: 209-212, 2017.
35) Murase T, Misawa K, Haramizu S, Hase T. Catechininduced activation of the LKB1/AMP-activated protein kinase pathway. Biochem Pharmacol 78: 78-84, 2009.

36) Curtis PJ, van der Velpen V, Berends L, Jennings A, Feelisch M, Umpleby AM, Evans M, Fernandez BO, Meiss MS, Minnion M, Potter J, Minihane AM, Kay CD, Rimm EB, Cassidy A. Blueberries improve biomarkers of cardiometabolic function in participants with metabolic syndrome-results from a 6 -month, double-blind, randomized controlled trial. Am J Clin Nutr 109: 1535-1545, 2019.

37）宮澤陽夫, 仲川清隆, 浅井 明：天然抗酸化物質の吸収と 代謝, 化学と生物, 38: 104-114, 2000.

38) Aruga N, Toriigahara M, Shibata M, Ishii T, Nakayama T, Osakabe N. Responses to a single dose of different polyphenols on the microcirculation and systemic circulation in rats. J Funct Foods 10: 355-363, 2014.

39) Lee KW, Kim YJ, Lee HJ, Lee CY. Cocoa has more phenolic phytochemicals and a higher antioxidant capacity than teas and red wine. J Agric Food Chem 51: 7292-7295, 2003

40) Oyama J, Maeda T, Sasaki M, Kozuma K, Ochiai R, Tokimitsu I, Taguchi S, Higuchi Y, Makino N. Green tea catechins improve human forearm vascular function and have potent anti-inflammatory and antiapoptotic effects in smokers. Intern Med 49: 25532559, 2010.

41) Oyama J, Maeda T, Kouzuma K, Ochiai R, Tokimitsu I, Higuchi Y, Sugano M, Makino N. Green tea catechins improve human forearm endothelial dysfunction and have antiatherosclerotic effects in smokers. Circ J 74: 578-588, 2010. 